\title{
FAKTOR PASIEN BERHUBUNGAN DENGAN ANGKA READMISSION PADA PELAKSANAAN DISCHARGE PLANNING PASIEN ACUTE CORONARY SYNDROME (ACS)
}

\author{
Romalina $^{1}$, M Rasjad Indra ${ }^{2}$, Dian Susmarini ${ }^{3}$ \\ ${ }^{1}$ Program Magister Keperawatan Peminatan Gawat Darurat, FK Universitas Brawijaya \\ Staf Pengajar Poltekkes Kemenkes Tanjungpinang/romlin17@gmail.com \\ ${ }^{2}$ Staf Pengajar Bagian Fisiologi, Departemen Anatomi dan Fisiologi FK Universitas \\ Brawijaya \\ ${ }^{3}$ Staf Pengajar Program Studi Magister Keperawatan, FK Universitas Brawijaya
}

Pasien acute coronary syndrome (ACS) beresiko mengalami readmission dalam 30-45 hari setelah keluar dari rumah sakit. Discharge planning bertujuan untuk menjamin kontinuitas kualitas perawatan antara rumah sakit dan pelayanan di komunitas. Tujuan dalam penelitian ini untuk mengetahui faktor pasien yang berhubungan dengan angka readmission pada pelaksanaan discharge planning pasien ACS di RSUD Dr. Saiful Anwar Malang. Rancangan dalam penelitian ini adalah analitik observasional dengan pendekatan prospektif. Penelitian dilaksanakan pada Agustus-Oktober 2014 di RSUD Dr. Saiful Anwar Malang. Sampel berjumlah 60 orang keluarga pasien ACS melalui pendekatan consecutive sampling. Pengumpulan data menggunakan kuesioner. Analisa data multivariat menggunakan regresi logistik dengan metode backward. Faktor prediktor angka readmission pasien ACS adalah komplikasi penyakit gagal jantung dan diabetes mellitus. Tenaga kesehatan perlu memperhatikan upaya pencegahan dengan memberikan edukasi ke pasien dan keluarga. Materi edukasi mengenai modifikasi faktor resiko (merokok, alkohol, tekanan darah, berat badan, nutrisi, aktivitas, olah raga, stres) dan manajemen pengobatan sesuai anjuran.

\section{SOME FACTORS OF PATIENTS RELATED TO THE SKORS OF READMISSION ON DOING DISCHARGE PLANNING OF}

\section{ACUTE CORONARY SYNDROMES' (ACS) PATIENTS}

Acute Coronary Syndrome's (ACS) patient has a risk getting readmission in 30 - 45 days after come back from hospital. Discharge planning has purpose to guaranty continuity of treatments' qualities among of hospital with communities' service. The purpose of this thesis is to determine patients' and nurses' factors that have contributing to the rate of readmission in doing discharge planning of ACSs' patients in RSUD Dr. Saiful Anwar Malang. The design of this thesis is a prospective observational analytic approach. The experiment was conducted in August to October 2014 in RSUD Dr. Saiful Anwar Malang. The sample is consisted of 60 families of ACS's patients with using consecutive sampling approach. The collecting of data uses questionnaire's sheet. The data analysis uses logistics' regretting with backward method. The predictors' factors of the readmission rate of Acute Coronary Syndrome (ACS) patients are the complication of the hearth failure and diabetes mellitus diseases. Health professionals need to pay attention to prevention effort to provide education to patients and families. The educational materials is in the form of the modification of risk factors (smoking, alcohol, blood pressure, personal weight, nutrition, activity, exercise, stress) and modification management as recommended.

Keywords: Acute Coronary Syndrome (ACS), Discharge Planning, Readmission. 


\section{PENDAHULUAN}

Acute Coronary Syndrome (ACS) adalah sekumpulan gejala akut yang timbul akibat kurangnya suplai darah ke otot jantung. World Health Organization (WHO) (2008) dalam Kemenkes (2012) mencatat 17,3 juta jiwa penduduk di dunia meninggal akibat Acute Coronary Syndrome (ACS). Sistem Informasi Rumah Sakit (SIRS) (2010-2011) menunjukkan bahwa penyakit jantung merupakan penyebab terbesar rawat inap.

Penanganan awal pasien Acute Coronary Syndrome (ACS) seharusnya dilakukan sejak serangan terjadi, kemudian dilanjutkan penanganan di rumah sakit. Penanganan dimulai dari Instalasi Gawat Darurat (IGD). Perawatan pasien di rumah sakit merupakan tanggung jawab tim kesehatan seperti : dokter, perawat dan tenaga kesehatan lainnya. Kerjasama yang baik dalam sebuah tim kesehatan sangat dibutuhkan untuk pemulihan kondisi pasien. Perawatan yang berkesinambungan dibutuhkan setelah pasien keluar dari rumah sakit, sehingga diperlukan discharge planning. Discharge planning bertujuan untuk menjamin kontinuitas kualitas perawatan antara rumah sakit dan pelayanan di komunitas. Efektivitas discharge planning dapat dinilai dari angka readmission pasien ke rumah sakit (Sheppard,LP dan Channer, KS, 2004).

Fitchet, et al (2011) membuktikan bahwa pasien Acute Coronary Syndrome (ACS) beresiko mengalami readmission dalam 30-45 hari setelah keluar dari rumah sakit. Untuk mengurangi resiko readmission pada pasien Acute Coronary Syndrome (ACS) perlu dibahas tentang faktorfaktor yang mempengaruhi discharge planning, antara lain : faktor pasien, faktor perawat dan faktor organisasi. Faktor pasien meliputi/: usia, jenis kelamin, kepemilikan asuransi kesehatan, tingkat pendidikan pasien, komplikasi medis, riwayat hospitalisasi, partisipasi keluarga pasien, tingkat keparahan penyakit, pernah dirawat di Instalasi Gawat Darurat (IGD), length of stay (LOS), kepatuhan follow up). Faktor perawat meliputi/: beban kerja, edukasi, motivasi dan sikap, pengetahuan, skill dan kompetensi. Faktor organisasi meliputi/: standard operational procedure (SOP), lingkungan fisik, kerja tim, alur dan tersedianya biaya) (Pronovost, Albert, Dorman and Morlock., 2002., Schalci, Saso, Rowlandson, Tennant., 2009 dan Lyratzopoulos, Havely, Gemmell and Cook., 2005).

Penelitian ini bertujuan untuk mengetahui faktor pasien yang berhubungan dengan angka readmission pada pelaksanaan discharge planning pasien Acute Coronary Syndrome (ACS) di RSUD Dr. Saiful Anwar Malang. Manfaat dari penelitian ini adalah memperbaiki sistem pelaksanaan discharge planning supaya lebih spesifik dan meningkatkan kualitas hidup pasien.

\section{METODE}

Rancangan dalam penelitian adalah observasional analitik melalui pendekatan prospective. Penelitian ini dilaksanakan di RSUD Dr. Saiful Anwar Malang dari bulan AgustusOktober 2014 dengan sampel berjumlah 60 orang melalui pendekatan consecutive sampling. Adapun kriteria inklusi sampel dalam penelitian ini adalah :

1. Pasien didiagnosis ACS oleh dokter baik UA, NSTEMI atau STEMI yang diberikan discharge 
planning dengan kondisi stabil (Hamm, et al., 2011)

2. Pasien ACS yang datang kembali ke IGD RSUD Dr. Saiful Anwar Malang dengan diagnosis ACS atau komplikasi minimal dalam kondisi P2 (ENA, 2001).

3. Mendapatkan perawatan dari bulan Agustus-Oktober 2014 di IRNA I RSUD Dr. Saiful Anwar Malang.

4. Ada keluarga yang mendampingi pasien acute coronary syndrome (ACS) selama berada di rawat inap di RSUD Dr. Saiful Anwar Malang.

Proses pengambilan data dengan menggunakan tiga instrumen. Instrumen pertama yaitu kuesioner yang didahului dengan mengisi formulir informed consent. Instrumen kedua berisikan data demografi pasien acute coronary syndrome (ACS) berisikan data identitas pasien, komplikasi medis, riwayat hospitalisasi. Instrumen ketiga yaitu kuesioner partisipasi keluarga pasien dalam discharge planning dengan menggunakan Relative's Questionnaire about Participation in Discharge Planning (R-QPD) yang diperkenalkan oleh Arnetz dan Arnetz (1996); Verho \& Arnetz (2003) dalam Almborg (2008) sebagai alat ukur mengetahui persepsi keluarga pasien terhadap kualitas perawatan. Uji reliabilitas menggunakan koefisien Cronbach's alpha 0.81 untuk faktor $R$ Information-Care/Support, 0.72 untuk faktor R-Information - Illness and 0.65 untuk faktor R-Goals and Needs (Bonneterree et al, 2011). Analisa data bivariat dengan uji chi square, multivariat dengan uji regresi logistik dengan metode backward.

\section{HASIL}

\section{Analisis univariat}

Terlihat bahwa lebih dari setengah responden berpartisipasi dalam discharge planning $(61,7 \%)$ (lihat tabel.1).

Tabel.1 Karakteristik responden berdasarkan variabel independen dan dependen

\begin{tabular}{cccc}
\hline Variabel & & $\begin{array}{c}\text { Jumlah } \\
\text { subjek }(\mathrm{n})\end{array}$ & $\begin{array}{c}\text { Prosentase } \\
(\%)\end{array}$ \\
\hline $\begin{array}{c}\text { Komplikasi } \\
\text { medis }\end{array}$ & Ya & 30 & 50 \\
$\begin{array}{c}\text { Riwayat } \\
\text { hospitalisasi } \\
\text { Partisipasi } \\
\text { keluarga } \\
\text { pasien }\end{array}$ & Ya & 30 & 50 \\
Yaadmission & Ya & 37 & 61,7 \\
\hline
\end{tabular}

Berdasarkan komplikasi medis (43,3\%), gagal jantung $(28,3 \%)$ dan didapat bahwa responden terbanyak diabetes mellitus (25\%) (lihat tabel.2). dengan komplikasi penyakit hipertensi

Tabel.2 Karakteristik responden berdasarkan komplikasi medis

\begin{tabular}{lccc}
\hline Variable & & $\begin{array}{c}\text { Jumlah } \\
\text { subjek (n) }\end{array}$ & $\begin{array}{c}\text { Prosentas } \\
\text { e (\%) }\end{array}$ \\
\hline Hipertensi & Ya & 26 & 43,3 \\
Gagal jantung & Ya & 17 & 28,3
\end{tabular}




\begin{tabular}{lccc}
$\begin{array}{l}\text { Diabetes } \\
\text { melitus } \\
\text { Pneumoni }\end{array}$ & Ya & 15 & 25 \\
$\begin{array}{l}\text { Ylkus } \\
\text { peptikum }\end{array}$ & Ya & 4 & 13,3 \\
$\begin{array}{l}\text { Ginjal kronik } \\
\text { Efusi pleura }\end{array}$ & Ya & 4 & 6,7 \\
\hline
\end{tabular}

Berdasarkan riwayat hospitalisasi didapat bahwa responden terbanyak dengan riwayat penyakit hipertensi
(35\%) dan diabetes melitus $(21,7 \%)$ (lihat tabel.3).

Tabel.3 Karakteristik responden berdasarkan riwayat hospitalisasi

\begin{tabular}{|c|c|c|c|}
\hline Variabel & & $\begin{array}{c}\text { Jumlah } \\
\text { subjek (n) }\end{array}$ & $\begin{array}{c}\text { Prosen } \\
\text { tase } \\
(\%)\end{array}$ \\
\hline Hipertensi & $\mathrm{Ya}$ & 21 & 35 \\
\hline $\begin{array}{l}\text { Diabetes } \\
\text { melitus }\end{array}$ & $\mathrm{Ya}$ & 13 & 21,7 \\
\hline Pneumoni & $\mathrm{Ya}$ & 5 & 8,3 \\
\hline $\begin{array}{l}\text { Penyakit } \\
\text { jantung }\end{array}$ & $\mathrm{Ya}$ & 4 & 6,7 \\
\hline Ginjal kronik & & 3 & 5 \\
\hline Efusi pleura & $\mathrm{Ya}$ & 1 & 1,7 \\
\hline Ulkus peptikum & $\mathrm{Ya}$ & 1 & 1,7 \\
\hline
\end{tabular}

\section{Analisis Bivariat}

Tabel.4 Hubungan variabel independen dengan dependen

\begin{tabular}{|c|c|c|c|c|c|c|}
\hline & & & & ission & & \\
\hline & & $\mathbf{N}$ & & & $p$ & $R R$ \\
\hline & & (60) & $\mathbf{n}$ & $\%$ & & \\
\hline Komplikasi medis & $\mathrm{Ya}$ & 30 & 18 & 60 & 0,000 & 4,500 \\
\hline Riwayat hospitalisasi & $\mathrm{Ya}$ & 30 & 15 & 50 & 0,032 & 2,143 \\
\hline $\begin{array}{l}\text { Partisipasi keluarga } \\
\text { pasien }\end{array}$ & $\mathrm{Ya}$ & 37 & 4 & 10,8 & 0,015 & 0,357 \\
\hline
\end{tabular}

Berdasarkan hasil analisis tabel.4 terdapat hubungan antara komplikasi medis dengan angka readmission pasien acute coronary syndrome (ACS) $(\mathrm{p}=0,000)$. Pasien dengan komplikasi medis beresiko mengalami readmission 4,5 kali lebih tinggi dibandingkan pasien yang tidak memiliki komplikasi medis.

Terdapat hubungan komplikasi penyakit gagal jantung dengan angka readmission pasien acute coronary syndrome (ACS) $(p=0,025)$. Pasien acute coronary syndrome (ACS) 
dengan komplikasi penyakit gagal jantung beresiko mengalami readmission 2 kali lebih tinggi dibandingkan pasien acute coronary syndrome (ACS) tanpa komplikasi penyakit gagal jantung. Terdapat hubungan antara komplikasi penyakit diabetes mellitus dengan angka readmission pasien acute coronary syndrome (ACS) $(p=0,030)$. Pasien acute coronary syndrome (ACS) dengan komplikasi penyakit diabetes mellitus beresiko mengalami readmission 2 kali lebih tinggi dibandingkan pasien acute coronary syndrome (ACS) tanpa komplikasi penyakit diabetes mellitus (lihat tabel.5).

Tabel.5 Hubungan komplikasi medis dengan angka readmission

\begin{tabular}{|c|c|c|c|c|c|c|}
\hline & & \multirow{2}{*}{$\begin{array}{c}\mathrm{N} \\
(60)\end{array}$} & \multicolumn{2}{|c|}{ Readmission } & \multirow[t]{2}{*}{$p$} & \multirow[t]{2}{*}{ RR } \\
\hline & & & $\mathrm{n}$ & $\%$ & & \\
\hline Hipertensi & $\mathrm{Ya}$ & 26 & 11 & 42,3 & 0,428 & 1,308 \\
\hline Gagal jantung & $\mathrm{Ya}$ & 17 & 10 & 58,8 & 0,025 & 2,108 \\
\hline Diabetes melitus & $\mathrm{Ya}$ & 15 & 9 & 60 & 0,030 & 2,077 \\
\hline Pneumonia & $\mathrm{Ya}$ & 8 & 4 & 50 & 0,449 & 1,444 \\
\hline Ulkus peptikum & $\mathrm{Ya}$ & 3 & 2 & 66,7 & 0,548 & 1,900 \\
\hline Ginjal kronik & $\mathrm{Ya}$ & 3 & 1 & 33,3 & 1,000 & 0,905 \\
\hline Efusi pleura & $\mathrm{Ya}$ & 2 & 1 & 50 & 1,000 & 1,381 \\
\hline
\end{tabular}

Terdapat hubungan antara riwayat hospitalisasi penyakit diabetes mellitus dengan angka readmission pasien acute coronary syndrome (ACS) $(\mathrm{p}=0,009)$. Pasien pasien acute coronary syndrome (ACS) dengan riwayat diabetes mellitus beresiko mengalami readmission 2,5 kali lebih tinggi dibandingkan pasien acute coronary syndrome (ACS) tanpa riwayat diabetes mellitus (lihat tabel.6)

Tabel.6 Hubungan riwayat hospitalisasi dengan angka readmission

\begin{tabular}{lccccccc}
\hline & & & \multicolumn{3}{c}{$\begin{array}{c}\text { Readmission } \\
\text { Ya }\end{array}$} & $p$ & RR \\
\cline { 5 - 6 } & & $\mathrm{N}$ & $(60)$ & $\mathrm{n}$ & $\%$ & & \\
\hline Hipertensi & Ya & 21 & 11 & 52,4 & 0,064 & 1,857 \\
Diabetes melitus & Ya & 13 & 9 & 69,2 & 0,009 & 2,503 \\
Pneumonia & Ya & 5 & 3 & 60 & 0,346 & 1,737 \\
Penyakit jantung & Ya & 4 & 3 & 75 & 0,135 & 2,211 \\
Ginjal kronik & Ya & 3 & 1 & 33,3 & 1,000 & 0,905 \\
Efusi pleura & Ya & 1 & 1 & 100 & 0,367 & 2,810 \\
\hline
\end{tabular}

\section{Analisis Multivariat}

Faktor yang berpengaruh terhadap angka readmission pada pasien acute coronary syndrome
(ACS) adalah komplikasi penyakit gagal jantung (RR 4,623) dan diabetes mellitus

(RR 4,383). 
Tabel.8 Analisis multivariat regresi logistik komplikasi medis

\begin{tabular}{lccc}
\hline \multicolumn{1}{c}{ Variabel } & Koefisien & $p$ & RR \\
\hline Diabetes melitus & 1,478 &, 032 & 4,383 \\
Gagal janrtung & 1,531 &, 021 & 4,623 \\
\hline
\end{tabular}

\section{PEMBAHASAN}

1. Hubungan komplikasi medis dengan angka readmission pasien acute coronary syndrome (ACS)

Hasil analisis univariat menunjukkan bahwa sebagian besar komplikasi medis pada pasien acute coronary syndrome (ACS) adalah penyakit hipertensi (43,3\%), gagal jantung $(28,3 \%)$ dan diabetes mellitus $(25 \%)$. Penelitian ini didukung oleh data U.S Department of Health and Human Services (2000) menunjukkan bahwa lebih dari 50 juta orang atau 1 dari 4 orang di Amerika Serikat mengalami hipertensi. Relevan dengan penelitian yang dilakukan oleh Oliveria, et al (2002)., Chobanian, et al (2003)., Luepker, et al (2006) menunjukkan bahwa pasien hipertensi berat (tekanan darah sistolik >180 $\mathrm{mmHg}$ dan tekanan darah diastolik $>110 \mathrm{mmHg}$ ) secara signifikan berhubungan dengan angka morbiditas dan mortalitas.

Hipertensi adalah peningkatan tekanan darah sistolik $\geq 140 \mathrm{mmHg}$ dan tekanan darah diastolik $\geq 90$ mmHg. Kestabilan tekanan darah dipengaruhi oleh beberapa hal, antara lain : sistem baroreseptor dan kemoreseptor arteri, pengaturan volume cairan tubuh, sistem reninangiotensin, autoregulasi vaskular. Baroreseptor berfungsi memonitor tekanan arteri melalui vasodilatasi dan memperlambat denyut jantung melalui nervus vagus. Kemoreseptor yang sensitif terhadap perubahan konsentrasi oksigen, karbon dioksida dan ion hidrogen dalam darah.
Penurunan konsentrasi oksigen arteri menyebabkan peningkatan tekanan. Perubahan volume cairan tubuh mempengaruhi tekanan arteri sistemik. Renin berperan sebagai vasokontriktor dan merangsang pelepasan aldosteron. Meningkatnya sistem syaraf simpatik, angiotensin II dan III menghambat ekskresi natrium sehingga terjadi peningkatan tekanan darah. Sekresi renin yang berlebihan menyebabkan meningkatnya resistensi vaskular perifer (Gavras dan Brunner, 2001.,Guyton dan Hall, 2004).

Hipertensi digolongkan berdasarkan jenis, penyebab dan tingkat keparahannya. Hipertensi primer terjadi jika tekanan darah sistolik dan diastolik meningkat secara bersamaan. Hipertensi sekunder disebabkan baik secara langsung atau tidak. Hipertensi labil disebabkan karena perubahan patologis pembuluh darah besar dan kecil. Dampak yang dapat ditimbulkan oleh hipertensi adalah terjadi iskemi atau infark jaringan otot jantung, otak ginjal dan retina. Hipertensi juga berhubungan dengan arterosklerosis, stroke, nefropati, penyakit vaskular, aneurisma aorta dan gagal jantung. Kondisi tingkat keparahan berhubungan dengan langsung dengan jumlah dan ukuran faktor-faktor risiko yang ada, lamanya keberadaan faktor resiko dan status penyakit yang menyertainya. Faktor resiko yang bisa dimodifikasi adalah diabetes mellitus, stres, obesitas, nutrisi, penyalah gunaan obat (rokok dan alkohol serta 
obatan terlarang (Black and Hawks, 2009).

Berdasarkan penelitian ini dapat disimpulkan bahwa faktor resiko hipertensi dapat memperburuk kondisi pasien acute coronary syndrome (ACS). Kondisi tingkat keparahan penyakit acute coronary syndrome (ACS) berhubungan langsung dengan adanya jumlah dan besarnya faktor resiko, lamanya keberadaan faktor resiko dan status penyakit yang menyertainya. Untuk itu perlu dilakukan upaya pencegahan perubahan gaya hidup melalui modifikasi faktor-faktor resiko (diabetes mellitus, stres, obesitas, nutrisi, merokok, penggunaan alkohol dan obat-obatan terlarang.

Hasil analisis bivariat menunjukkan bahwa terdapat hubungan komplikasi penyakit gagal jantung dengan angka readmission pasien acute coronary syndrome (ACS) $\quad(p=0,025)$. Pasien acute coronary syndrome (ACS) dengan komplikasi penyakit gagal jantung beresiko mengalami readmission 2 kali lebih tinggi dibandingkan pasien acute coronary syndrome (ACS) tanpa komplikasi penyakit gagal jantung. Penelitian ini didukung oleh Lai, J.,Lin, H.,Lai, Y.,Lin, P., Chang, S., Tang, G (2012) menunjukkan bahwa pasien dengan komplikasi penyakit gagal jantung beresiko mengalami readmission 1,214 kali dibanding dengan pasien lain. Dari 59.652 pasien yang dirawat dengan komplikasi gagal jantung, 11199 (19\%) mengalami readmission dalam 30 hari setelah dipulangkan dari rumah sakit ( $\mathrm{Au}$ et al., 2012).

Hipertensi merupakan salah satu faktor resiko penyakit gagal jantung sehingga dibutuhkan pencegahan baik primer atau sekunder (Psaty, et al.,2001 dan National Heart, Lung and Blood Institute Joint National Committee on Prevention, Detection, Evaluation and Treatment of High Blood Pressure, 2003). Alasan readmission pada pasien gagal jantung adalah arrhythmia, ischemia, penyakit paru, insufisiensi ginjal dan anemi (Annema, Luttik, Jaarsma., 2009).

Gagal jantung terjadi karena perubahan fungsi sistolik dan diastolik ventrikel kiri. Kegagalan ini akibat gangguan struktur atau penyakit instrinsik. Faktor instrinsik penyebab gagal jantung adalah penyakit arteri koroner, penyebab lain adalah infark miokardium, selama infark, otot jantung kekurangan darah dan jaringan mengalami kematian sehingga tidak dapat berkontraksi. Penyebab instrinsik lain penyakit katup, kardiomiopati dan disritmia. Kondisi ini menekan jantung dari luar dan pengisian ventrikel dan kontraktilitas miokardium terganggu. Kompresi pada jantung akan mengurangi relaksasi diastolik sehingga meningkatkan tekanan diastolik dan menghambat aliran darah keluar dari jantung. Faktor ekstrinsik penyebab gagal jantung adalah peningkatan afterload (hipertensi), peningkatan volume sekuncup atau preload dan peningkatan kebutuhan tubuh (tirotoksikosis dan kematian). Volume darah di ventrikel kiri meningkat menyebabkan beban jantung abnormal (preload dan afterload). Tahanan vaskular perifer dan tekanan darah yang tinggi akan memaksa ventrikel bekerja lebih keras untuk mengejeksi darah. Akibat tekanan darah yang tinggi jangka panjang menyebabkan ventrikel mengalami kegagalan (Baig, et al.,1998; Guyton and Hall, 2004).

Hasil analisis bivariat juga menunjukkan bahwa terdapat 
hubungan antara komplikasi penyakit diabetes mellitus dengan angka readmission pasien acute coronary syndrome (ACS) $(p=0,030)$. Pasien acute coronary syndrome (ACS) dengan komplikasi penyakit diabetes mellitus beresiko mengalami readmission 2 kali lebih tinggi dibandingkan pasien acute coronary syndrome (ACS) tanpa komplikasi penyakit diabetes mellitus. Penelitian ini di dukung oleh Deek, Skouri, Noureddine (2014) bahwa terdapat hubungan antara komplikasi penyakit diabetes mellitus dengan angka readmission $(p=0,006)$. Prevalensi penyakit pembuluh darah koroner terjadi pada populasi Non Insuline Dependent Diabetes Mellitus (NIIDDM) dan resiko terjadi penyakit jantung koroner 2 kali lebih tinggi dibandingkan pasien tanpa diabetes mellitus (Bardsley dan Ratner, 2006). Dari 5314 pasien gagal jantung, 1519 pasien dengan diagnosis diabetes mellitus (Romero et al, 2013).

Diabetes mellitus diklasifikasi menjadi Insuline Dependent Diabetes Mellitus (IDDM) dan Non Insuline Dependent Diabetes Mellitus (NIIDDM) (Expert committee on the diagnosis and classification of diabetes mellitus, 2003). Non Insuline Dependent Diabetes Mellitus (NIIDDM) terjadi karena kurangnya respon sel beta terhadap kondisi hiperglikemi yang disebut desentisasi. Penurunan sensitivitas insulin terhadap kadar glukosa, diikuti dengan ketidakmampuan otot dan jaringan lemak untuk menyerap glukosa disebut resistensi insulin. Tidak adekuatnya Insulin menyebabkan kadar glukosa darah meningkat. Untuk menyeimbangkan kondisi tersebut ginjal mengeluarkan glukosa berlebihan sehingga glukosa ditemukan dalam urine disebut glukosuria. Metabolisme lemak tinggi menyebabkan produksi keton, keton terakumulasi dalam darah dan dikeluarkan melalui ginjal dan paru, ahirnya keton ditemukan di urine dan darah. Pengeluaran keton merangsang pengeluaran natrium mengakibatkan natrium berkurang terjadi asidosis dan meningkatkan tekanan osmotik mengakibatkan kehilangan cairan (Guyton and Hall, 2004.,Bardsley and Ratner, 2006).

Pasien unstable angina (UA)/non ST elevation myocardial infarction (NSTEMI) yang disertai penyakit diabetes mellitus berpeluang untuk terjadi trombus dan flaque dibanding pasien tanpa diabetes mellitus. Hal ini terjadi karena bertambahnya usia seseorang, kondisi obesitas, kurangnya aktivitas fisik (Grundy, Cleeman, Merz., 2004). Resistensi insulin, tingginya low density lipoprotein (LDL), rendahnya kadar hight density lipoprotein (HDL) insulin dalam darah meningkat dan kondisi hipertensi. Kondisi tersebut menyebabkan gangguan sistem peradaran darah dan proses pembekuan darah, peningkatan tekanan pada dinding pembuluh darah, abnormalitas metabolisme yang akhirnya menimbulkan flaque besar di pembuluh darah sehingga terjadi ruptur atau tombosis. Komplikasi diabetes mellitus tipe 2 antara lain : komplikasi makrovaskular dan mikrovaskular. Komplikasi makrovaskular adalah penyakit arteri koroner, serebrovaskular, pembuluh perifer. Komplikasi mikrovaskular adalah perubahan pada retina, ginjal, kapiler perifer diabetes mellitus (Black and Hawks, 2009).

Kebanyakan kasus diabetes mellitus tipe 2 berhubungan dengan gaya hidup. Hal ini didukung oleh penelitian Tuomilehto, Lindstrom dan Ericson (2001) dan Yamaoka dan 
Tango (2005) membuktikan bahwa intervensi gaya hidup (diet, aktivitas fisik, berat badan) menurunkan progres kambuhnya penyakit diabetes mellitus. Berdasarkan penelitian ini, dapat disimpulkan bahwa beratnya komplikasi yang disebabkan oleh diabetes mellitus tipe 2 sehingga perlu penatalaksanaan yang tepat. Penatalaksanaannya antara lain : berat badan ideal, diet seimbang, memperbaiki profil lemak, mengurangi intoleransi glukosa, menurunkan tekanan darah, tidak merokok dan pengobatan.

Hasil analisis multivariat menunjukkan bahwa faktor yang berpengaruh terhadap angka readmission pada pasien acute coronary syndrome (ACS) adalah komplikasi penyakit gagal jantung $(\mathrm{p}=$ 0,021 RR 4,623 95\%CI 1,254-17,042) dan diabetes mellitus ( $\mathrm{p}=0,032 \mathrm{RR}$ $4,383 \quad 95 \%$ CI 1,137-16,895). Penelitian ini didukung oleh Franchi, et al (2013) mengatakan bahwa kompleksnya suatu penyakit akan mempengaruhi angka readmission. Penelitian yang serupa dilakukan oleh Anderson, et al (2013) membuktikan bahwa komplikasi penyakit diabetes mellitus sebagai prediktor readmission pada pasien dengan unstable angina (UA). Wild et al (2000) menunjukkan bahwa komplikasi penyakit diabetes mellitus tipe 2 merupakan independen prediktor penyebab rawat inap, readmission dan kematian pada pasien dengan gagal jantung. Andres, et al (2012) membuktikan bahwa prediktor readmission adalah komplikasi penyakit jantung $(p<0,001$, OR 1,69 95\% CI 1,47-1,93).

Dari kenyataan ini dapat disimpulkan bahwa readmission pada pasien acute coronary syndrome (ACS) berhubungan dengan komplikasi penyakit gagal jantung dan diabetes mellitus. Kedua penyakit ini sangat berhubungan antara satu dengan yang lain. Gagal jantung merupakan komplikasi dari penyakit diabetes mellitus dan Hipertensi. Oleh karena itu, dibutuhkan upaya pencegahan readmission pasien gagal jantung dengan cara mengoptimalkan perawatan, memperbaiki ketaatan dan perilaku perawatan diri dari pasien. Dalam penatalaksanaan pasien acute coronary syndrome (ACS) dibutuhkan kerjasama tim tenaga kesehatan dari berbagai multi disipliner. Upaya pencegahan yang dilakukan adalah perubahan gaya hidup dengan modifikasi faktor-faktor resiko, pengobatan diabetes mellitu dan hipertensi.

2. Hubungan riwayat hospitalisasi dengan angka readmission pasien acute coronary syndrome (ACS)

Hasil analisis univariat berdasarkan riwayat hospitalisasi menunjukkan bahwa responden terbanyak adalah dengan riwayat penyakit hipertensi (35\%) dan diabetes melitus (21,7\%). Penelitian ini didukung oleh Lingman, et al (2009) menunjukkan bahwa dari 2329 pasien acute coronary syndrome (ACS), yang memiliki riwayat penyakit hipertensi 974 (42\%) dan diabetes mellitus 446 (19\%). Relevan dengan penelitian yang dilakukan oleh Deek, Skouri, Noureddine (2014) terbukti bahwa dari 187 pasien gagal jantung, yang memiliki riwayat penyakit hipertensi (61\%) dan diabetes mellitus $(41,7 \%)$.

Tingginya angka hipertensi tidak terlepas dari faktor umur, jenis kelamin (perempuan), tingginya nilai left ventricular ejection fraction (LVEF). Tingginya angka kejadian diabetes mellitus sangat berkaitan 
dengan perubahan gaya hidup secara intensif. Hipertensi berkontribusi terhadap kegagalan fungsi organ dan pembuluh darah. Untuk itu perlu penyuluhan mengenai faktor resiko dan cara pencegahan diabetes mellitus tipe 2. Tindakan memelihara kesehatan adalah pertama : skrining bagi individu beresiko tinggi (umur>45 tahun, pasien hipertensi dan hiperlipidemi, pasien denganglukosa 2 jam setelah makan sebelumnya, perempuan dengan diabetes mellitus gestasional, perempuan dengan sindrom polikistik ovarium. Kedua, mengkaji secara periodik glukosa. Ketiga, gunakan strategi untuk mengurangi komplikasi diabetes mellitus (menangani faktor resiko seperti : hipertensi, merokok, hiperlipidemi dan pemakaian obat nefrotoksik). Keempat, lakukan perawatan kaki harian. Kelima, mencegah hipoglikemi atau hiperglikemi dengan monitor ketat kadar glukosa darah (Black and Hawks, 2009). Melihat kondisi tersebut dibutuhkan program pencegahan diabetes mellitus seperti pendidikan gaya hidup tentang diet dan olahraga, penurunan berat badan, menurunkan angka insiden diabetes mellitus pada masyarakat.

Hasil analisis bivariat menunjukkan bahwa terdapat hubungan antara riwayat penyakit diabetes mellitus $(\mathrm{p}=0,009)$ dengan angka readmission pasien acute coronary syndrome (ACS). Pasien acute coronary syndrome (ACS) dengan riwayat hospitalisasi penyakit diabetes mellitus (DM) beresiko mengalami readmission 2,5 kali lebih tinggi dibandingkan pasien ACS yang tidak memiliki riwayat hospitalisasi penyakit diabetes mellitus. Penelitian ini didukung oleh Franchi, et al (2013) bahwa riwayat hospitalisasi $(\mathrm{p}=0,0009$
OR $1,92, \quad \mathrm{CI} 95 \% \quad 1,31-2,82)$ berhubungan dengan readmission. Deek et al (2014) membuktikan bahwa prediktor readmission pada pasien gagal jantung adalah riwayat penyakit diabetes mellitus ( $\mathrm{p}=0,019$ OR 2.681 95\%CI 1.176-6.110) dan coronary artery disease (CAD) $(\mathrm{p}=0,004$ OR 3.300 95\% CI 1.462-7.449). Lingman et al (2009) menunjukkan bahwa indikator resiko morbiditas dan mortalitas pada pasien acute coronary syndrome (ACS) adalah riwayat penyakit diabetes mellitus sebelumnya $(\mathrm{p}<0,0001 \quad$ HR 1.79 95\%CI $1.52-$ 2.10).

Ada lima faktor penting yang perlu digali apakah seseorang memiliki kemungkinan iskemik atau penyakit arteri koroner antaralain : sifat gejala nyeri dada, riwayat penyakit arteri koroner sebelumnya, jenis kelamin, umur, faktor resiko lainnya (Anderson et al, 2013). Rubin, et al (2014) membuktikan ada lima hal yang mempengaruhi risiko readmssion pada pasien diabetes mellitus adalah kurang pengetahuan (pengetahuan tentang diabetes mellitus dan instruksi discharge planning), kegagalan sistem kesehatan (proses discharge planning), kegagalan mengontrol faktor resiko (mengikuti instruksi, pengobatan dan dukungan sosial), hilang kontrol terhadap penyakitnya.

Metode edukasi digunakan untuk mencegah resiko readmission pada pasien dengan diabetes mellitus. Hal - hal yang perlu dijelaskan dalam edukasi klien diabetes mellitus adalah fungsi dan struktur pankreas., definisi diabetes mellitus dan hubungannya terhadap fungsi abnormal pankreas., gejala hipoglikemi., metode mengendalikan hiperglikemi (diet, olahraga, obat anti diabetes oral, insulin : bagaimana, kapan, dimana, mengapa memberikan insulin dan 
penyimpanan, pembuangan insulin dan jarum., pemantauan sendiri harian kadar glukosa darah., pemeriksaan keton dalam urin., komplikasi diabetes mellitus (definisi, penyebab, gejala, pengobatan) baik akut (hipoglikemi,ketoasidosis diabetik) dan kronis (makrovaskular dan mikrovaskular) (ADA, 2013 dan Foley, 2006).

3. Hubungan partisipasi keluarga pasien dengan angka readmission pasien acute coronary syndrome (ACS)

Hasil analisis univariat menunjukkan bahwa sebagian besar responden berpartisipasi dalam discharge planning (61,7\%). Hasil analisis bivariat menunjukkan bahwa terdapat hubungan antara partisipasi keluarga pasien dengan angka readmission pasien acute coronary syndrome (ACS) di RSUD Dr. Saiful Anwar Malang sebesar $(\mathrm{p}=0,015)$. Penelitian ini didukung oleh Clark, et al (2005) membuktikan bahwa keterlibatan pasien dan keluarga dalam discharge planning menyebabkan turunnya angka readmission.

Bowles, et al (2002) menunjukkan bahwa lebih dari $56 \%$ pasien yang dipulangkan dari rumah sakit tidak menerima informasi perawatan dirumah meskipun sudah dilakukan skrening kebutuhan sebelumnya. Kebutuhan perawatan pasien setelah di rumah biasanya diberikan oleh keluarga, dimulai dari kebutuhan dasar sampai dengan kebutuhan medis (seperti : perawatan luka, terapi fisik dan lain-lain). Peran keluarga sebagai pemberi perawatan merupakan komponen penting dalam discharge planning. Keterlibatan pasien dan keluarga dalam discharge planning menunjang perawatan di rumah, karena sebagai jembatan dalam proses transisi perawatan dari rumah sakit ke rumah (Clark et al, 2005).

Melihat kondisi tersebut, pasien dan keluarga membutuhkan dukungan untuk mengerti tentang penyakitnya, kepatuhan dengan rekomendasi (faktor - faktor resiko yang bisa dimodifikasi, perawatan, pengobatan, rehabilitasi). Dibutuhkan keikutsertaan keluarga dalam menentukan tujuan dan mengidentifikasi kebutuhan pasien dan memperbaiki persepsi tentang penyakit keluarganya terutama pasien acute coronary syndrome (ACS).

\section{KESIMPULAN}

Kesimpulan dalam penelitian ini adalah faktor komplikasi medis, riwayat hospitalisasi, beban kerja perawat, meningkatkan angka readmission pasien Acute Coronary Syndrome (ACS) dan faktor edukasi pasien serta partisipasi keluarga pasien menurunkan angka readmission pasien Acute Coronary Syndrome (ACS). Faktor yang berpengaruh terhadap angka readmission pasien acute coronary syndrome (ACS) adalah komplikasi medis dan edukasi pasien. Saran dalam penelitian ini adalah : Penelitian selanjutnya tentang faktor pasien \& perawat serta organisasi lain yang mempengaruhi angka readmission pasien acute coronary syndrome (ACS) dengan menggunakan analisis multivariat Structural equation modeling (SEM). Komplikasi penyakit diabetes mellitus dan gagal jantung merupakan tanda resiko tinggi terjadi readmission pada pasien acute coronary syndrome (ACS). Untuk itu, tenaga kesehatan perlu memperhatikan upaya pencegahan dengan memberikan edukasi ke pasien dan keluarga. Materi edukasi mengenai modifikasi faktor resiko (merokok, alkohol, tekanan 
darah, berat badan, nutrisi, aktivitas, olah raga, stres) dan manajemen pengobatan sesuai anjuran.

\section{DAFTAR PUSTAKA}

Almborg,A. 2008. Perceived participation in discharge planning and health related quality of life after stroke. School of health sciences, jönköping university dissertation series No. 4.

Anderson,J.L., $\quad$ Adams,C.D., Antman,E.M., Bridges,C.R., Califf, R.M., Casey, D.E., Jr, Chavey II, W.E. 2013. ACCF/AHA Focused update incorporated into the ACCF/AHA 2007 guidelines for the management of patients with unstable angina/non-st-elevation myocardial infarction: a report of the american college of cardiology foundation/american heart association task force on practice. Circulation. 127:1-188.

Andres, E., Cordero, A., Magan, P., Alegria, E., Leon, M., Luengo, E., Botaya, R.M., Ortiz, L.G., Casasnovas, J.A. 2012. Long-term mortality and hospital readmission after acute myocardial infarction : an eight- year follow up study. Rev.Esp Cardiol. 65(5):414-420.

American Diabetes Association. 2013. Economic costs of diabetes in the U.S. in 2012. Diabetes Care. 36:1033-1046.

Annema, C., Luttik, M., Jaarsma, T. 2009. Reason for readmission in heart failure : perspective of patients, care givers, cardiologists, anda heart failure nurses. Heart and lung. 38(5):427-43

Au,A.G., McAlister, F.A., Bakal, J.A., Ezekowitz, J., Kaul, P., Walraven, C.V. 2012. Predicting the risk of unplanned readmission or death within 30 days of discharge after a heart failure hospitalization. American Heart Journal. 164(3):365-372.

Bonneterre,V., Ehlinger,V., Balducci, F., Caroly, S., Jolivet., A., Sobaszek, A., de Gaudemaris, R., Lang, T. 2011. Validation of an instrument for measuring psychosocial and organisational work constraints detrimental to health among hospital workers : The NWI-EO questionnaire. International Journal of Nursing Studies. 48:557- 567.

Baig, M.K et al. 1998. The pathophysiology of advance heart failure. Heart and Lung,. 28:8797.

Black and Hawks, 2009. Medicalsurgical nursing : clinical management for positive outcomes. Elsevier (Singapore) Pte Ltd.

Bardsley, J dan Ratner, R.E. 2006. Pathophysiology of the metabolic disorder. Dalam C. Mensing (editor), the art and science of diabetes self management : a desk reference for healthcare professionals. Chicago:American Association of Diabetes Educators. 143-161.

Bowles, K.H., Naylor, M.D., Foust, J.B.2002. Patient characteristics at hospital discharge and a comparison of home care referral decisions. $J$ Am Geriatr soc. 50:336-342.

Chobanian AV, Bakris GL, Black HR, et al. 2003. The Seventh Report of the Joint National Committee on Prevention, Detection, Evaluation, and Treatment of High Blood Pressure: the JNC 7 report. JAMA. 289: 2560-72.

Clark, P.A., Drain, M.,Gesell, S.B., Mylod, D.M., Kaldenberg, D.O., 
Hamilton, J. 2005. Patient perceptions of quality in discharge instruction. Patient education and counseling 59:56-68.

Deek, H., Skouri, H., Noureddine, S. 2014. Readmission rates and related factors in heart failure patients: A study in Lebanon. Collegian. 298:1-8.

Department of Health and Human Services, 2000. National Institutes of Health. National Heart, Lung, and Blood Institute. Your Guide to Lowering Your Cholesterol with Therapeutic Lifestyle Changes update. Available at: http://www.nhlbi.nih.gov/health/p ublic/heart/chol/chol_tlc.pdf. Accessed November 12, 2014.

Fitchett, D.H., Theroux, P., Brophy, J.M., Cantor, W.J., Cox, J.L., Gupta, M., Kertland, H., et al. 2011. Assessment and management of acute coronary syndrome (ACS) : a canadian perspective on current guidelinerecommended treatment-part 1 : non ST segment elevation ACS. Canadian journal of cardiology. 27:S387-S401.

Franchi, C., Nobili, A., Mari, D., Tettamanti, M., Djade, C.D., Pasina, L., Salerno, et al. 2013. Risk factors for hospital readmission of elderly patients. European Journal of Internal Medicine 24: 45-51.

Foley, S. 2006. Investing in diabetes management. American journal of nursing.106(4):19-20.

Gavras, H dan Brunner, HR. 2001. Role of angiotension and its inhibition in hypertension, iscemic heart disease and heart failure. Hypertension. 37:342.
Guyton, A and Hall, J. 2004. Textbook of medical phisiology. Elsevier (Singapore) Pte Ltd.

Grundy SM, Cleeman JI, Merz CN, et al. 2004. Implications of recent clinical trials for the national cholesterol education program adult treatment panel III guidelines. Circulation.110:22739.

Hamm,CW., Bassand, J., Agewall, S., Bax, J., Boersma, E., Bueno, H., Caso, P., et al. 2011. ESC Guidelines for the management of acute coronary syndromes in patients presenting without persistent ST-segment elevation. European Heart Journal. 32:2999-3054.

Kemenkes RI. 2012. Buletin : Jendela data dan informasi kesehatan : penyakit tidak menular. ISSN 2008 - 270X.

Lai, J.,Lin, H.,Lai, Y.,Lin, P., Chang, S., Tang, G. 2012. Readmission to the intensive care unit : a population-based approach. Journal of The Formosan Association. 111:504-509.

Luepker RV, Arnett DK, Jacobs Jr DR, et al. 2006. Trends in blood pressure, hypertension control, and stroke mortality: the Minnesota Heart Survey. Am J Med 119:42-9.

Lyratzopoulos,G., Havely,D., Gemmell and Cook, G.A. 2005. Factors influencing emergency medical readmission risk in a UK district general hospital: A prospective study. $B M C$ Emergency Medicine 5(1):1-9.

Lingman, M., Herlitz, J., Bergfeldt, L., Karlsson, T., Caidahl, K., Hartford, M. 2009. Acute coronary syndromes - The prognostic impact of 
hypertension, diabetes and its combination on long-term outcome. International Journal of Cardiology 137:29-36

National Heart, Lung, And Blood Institute Joint National Committee On Prevention, Detection, Evaluation And Treatment Of High Blood Pressure 2003. The Seventh Report Of The Joint National Committee On Prevention, Detection, Evaluation And Treatment Of High Blood Pressure : The JNC-7 Report. Journal Of The American Medical Association. 289(19):2560-2572.

Oliveria, SA., Lapuerta, P, McCarthy, $\mathrm{BD}$, et al. 2002. Physicianrelated barriers to the effective management of uncontrolled hypertension. Arch Intern Med 162:413-20.

Pronovost, P., Albert, W.W., Dorman, T and Morlock, L. 2002. Building safety into ICU care. Journal of critical care. 17(2):78-85.

Psaty BM, Furberg CD, Kuller LH, et al. 2001. Association between blood pressure level and the risk of myocardial infarction, stroke and total mortality: the cardiovascular health study. Arch Intern Med. 161:1183-92.

Rubin, D.J., Jackson, K.D., Jhingan, R., Golden, S.H., Paranjape, A. 2014. Early readmission among patients with diabetes: A qualitative assessment of contributing factors. Journal of Diabetes and Its Complications 28:869-873.
Romero,S.P., Antonio Garcia-Egido, Miguel A. Escobar, Jose L. Andrey, Ramón Corzo, Virginia Perez, Gloria J. Garcia-Domiguez, Francisco Gomez. 2013. Impact Of New-Onset Diabetes Mellitus And Glycemic Control On The Prognosis Of Heart Failure Patients: A Propensity-Matched Study In The Community. International Journal Of Cardiology 167:1206-1216

Schalci,Z., Saso, S., Li, HK., Rowlandson, E., Tennant, RC.2009. Factors influencing hospital readmission rates after acute medical treatment. Clinical medicine 9(5):426-430.

Sheppard,LP dan Channer,KS. 2004. Acute coronary syndromes. Continuing Education in Anaesthesia, Critical Care \& Pain 4(6):175-180.

Tuomilehto, J., Lindstrom, J dan Ericson, J.G. 2001. Prevention of type 2 diabetes mellitus by changes in lifestyle among subjects with impaired glucose tolerance. New england journal of medicine. 344:1343-1350.

Wild, S., Roglic,G.,sicree, et al. 2000. Global prevalence of diabetes : estimates for the year 2000 and projections for 2030. Diabetes care, 27 1047-1053)

Yamaoka, K dan Tango, T. 2005. Lifestyle education programmes lower glucose concentrations and reduce the incidence of type 2 diabetes : A meta analysis of randomized controlled trials. Diabetes care. 28:2780-2786. 